\title{
POLSKA REFLEKSJA O MUZYCE W KINIE DŹWIĘKOWYM W LATACH TRZYDZIESTYCH XX WIEKU. GŁÓWNE IDEE I PERSPEKTYWY BADAWCZE W MUZYKOLOGII
}

$I$. Początki filmu dźwiękowego w Polsce zwykło nazywać się opóźnionymi. Choć - pierwsze tego typu produkcje pojawiły się w I930 r. ${ }^{\text {I }}$, jeszcze w l. I93I-32 produkowano u nas filmy jednocześnie w wersji niemej i dźwiękowej, a do I932 r. dźwięk był nagrywany wyłącznie na płytach gramofonowych, co powodowało sporo problemów z jego nienaganną synchronizacją z obrazem - dopiero w roku następnym zaczęto robić filmy zbierające obraz i dźwięk na jednej taśmie ${ }^{2}$. Tym niemniej, odkąd muzykę odtwarzaną z gramofonu czy graną przez tapera lub zespoły muzyczne na sali kinowej zastępować zaczęła muzyka nagrywana i synchronizowana, rozlegająca się wprost z ekranu, coraz częściej stawiano pytania nie tylko o jej bieżący status, lecz także o wyobrażenia o tym, czym i jaka mogłaby lub/i powinna być.

Do wykonania i zarejestrowania muzyki w Moralności pani Dulskiej-pierwszym polskim filmie dźwiękowym - zatrudniono najlepszych rodzimych artystów i zespoły, a skomponowanie muzyki powierzono Ludomirowi Różyckiemu, co było zapewne miarą wysokiej pozycji tego kompozytora w polskim środowisku muzycznym i docenieniem różnorodności jego twórczych zainteresowań3 ${ }^{3}$ Nie bez znaczenia był

I Pierwsza była Moralność Pani Dulskiej w reżyserii Bolesława Newolina, która miała swoją premierę 29 III I930 roku. Zob. na ten temat m.in.: „Twórczość filmowa... komuś musi na niej zależeć. Z Edwardem Zajičkiem rozmawia Monika Talarczyk-Gubała", Pleograf. Kwartalnik Akademii Polskiego Filmu I (20I6) nr 4, strona http://akademiapolskiegofilmu.pl/pl/historia-polskiego-filmu/pleograf/powrot-do-gwiazd/6/ tworczosc-filmowa-komus-musi-na-niej-zalezec-z-edwardem-zaji-kiem-rozmawia-monika-talarczykgubala/576, dostęp Io III 20I8; Tadeusz Lubelski, Historia kina polskiego. Twórcy, filmy, konteksty, Chorzów 2009, s. 74-80.

2 Zob. Władysław Jewsiewicki, Polska kinematografia w okresie filmu dźwiękowego w latach 1930-I939, Łódź I967, s. II. Pierwszą polską produkcją z tzw. dźwiękiem optycznym (w systemie Tobis-Klangfilm) był film Każdemu wolno kochać Mieczysława Krawicza i Janusza Warneckiego, który miał premierę w roku 1933.

3 Przypomnijmy, że Różycki był także autorem „opery filmowej” Mtyn diabelski (I928-30), o której tak pisał recenzent po premierze w Teatrze Wielkim w Poznaniu 2I II I93I r.: „Obrazy zmieniają się jak w filmie. Nic nie pomogło to, że tytuł Mtyna brzmi na afiszu «opera», podczas gdy poprzednio miał to być 
też zapewne fakt uhonorowania kompozytora w I930 r. nagrodą państwową za operę Eros $i$ Psyche. W relacji ze studia nagraniowego w Wiedniu o warstwie dźwiękowej tej przełomowej produkcji pisano:

Muzyka, cudowne pienia, rozmowy, gwizdy, trzaski, piekło i niebo na przemian - a wszystkie te dźwięki rejestrują czułe aparaty i przenoszą na płyty, aby potem oddać w doskonałej zgodności z akcją wyświetlaną na ekranie. Idzie tutaj właśnie o tę zgodność. [...] Oryginalne motywy do filmu (między innymi piękny boston i blues) skomponował mistrz Ludomir Różycki. Najznakomitsza orkiestra (specjalny zespół Filharmonii Warszawskiej) wykonała tę nową muzykę pod batutą Bronisława Szulca, dzielnego współpracownika Ludomira Różyckiego. Niemałą rolę odegrały chóry Kazury i Lachmana, produkujące pieśni dożynkowe. Partie śpiewne wykonali między innymi PP. Wiktor Bregy z Opery warszawskiej i Stefania Różycka4

Wiadomo także, że z Moralności pani Dulskiej pochodziła pierwsza polska piosenka filmowa. Napisana przez Różyckiego Hanka ukazała się na płytach wkrótce po premierze filmu z tekstem Juliana Krzewińskiego i była anonsowana jako „motyw przewodni” z filmu, co zapoczątkowało pewną stałą praktykę promocji filmowych melodii. Sam kompozytor w wywiadzie dla Kuriera Filmowego przyznawał natomiast, że przy pisaniu ilustracji korzystał także „z bogatych motywów ludowych”, czego efektem była m.in. chóralna Kotysanka oraz Dożynkis.

Z kolei do Janka muzykanta mającego premierę jesienią I930 r. i reklamowanego jako „pierwszy film dźwiękowo-śpiewny” ilustrację muzyczną opracowała inna wielka postać polskiej muzyki - Grzegorz Fitelberg, podczas gdy Leon Schiller sprawował kierownictwo muzyczne. Prasa z ekscytacją donosiła o kulisach produkcji filmu i sesji nagraniowej w atelier filmów dźwiękowych w Berlinie pod dyrekcją Fitelberga ${ }^{6}$. W filmie wystąpili m.in. Maria Malicka i debiutujący Witold Conti, a na ścieżce muzycznej znalazły się piosenki w wykonaniu Kazimierza Krukowskiego i Adolfa Dymszy. Płyty z nagraniami zaginęły, więc charakteru tej muzyki można się tylko domyślać na podstawie sądów współczesnych. Czytamy wśród nich na przykład poniższą, będącą niewątpliwie świadectwem estetycznego zadowolenia, relację bodaj najbardziej wpływowej polskiej krytyczki filmowej do I939 r., Stefanii Zahorskiej:

\footnotetext{
"film sceniczny», jak mnie zapewniano. Niełatwo zaprzeć się swego pochodzenia, gdy kto należy do tak wyrazistej rasy, jaką wychowała sobie Dziesiąta Muza, matka rodu ekranowego. Raz jesteśmy w wytwórni filmowej, raz w obłokach na aeroplanie, raz w ajencji depesz, raz w nocnej spelunce, girlsy tańczą, opryszki kradną, kwiaciarki kochają się z lotnikami. Jest wszystko, czego widz filmowy tak bardzo łaknie w dziedzinie sensacji i naskórkowego wstrząsu. Sam ekstrakt współczesności”, zob.: Witold Noskowski, „Premiera nowej opery Ludomira Różyckiego”, Muzyka 8 (I93I) nr 3, s. I54.

4 „Moralność pani Dulskiej”, Kino I (1930) nr 4, s. 8-9.

5 „Kuchnia Twardowskiego. Co mówi kompozytor Ludomir Różycki”, Kurier Filmowy 2 (1930) nr IO, s. 3.

6 „Za kulisami filmu dźwiękowego”, Kino I (I930) nr 32, s. I2.
} 


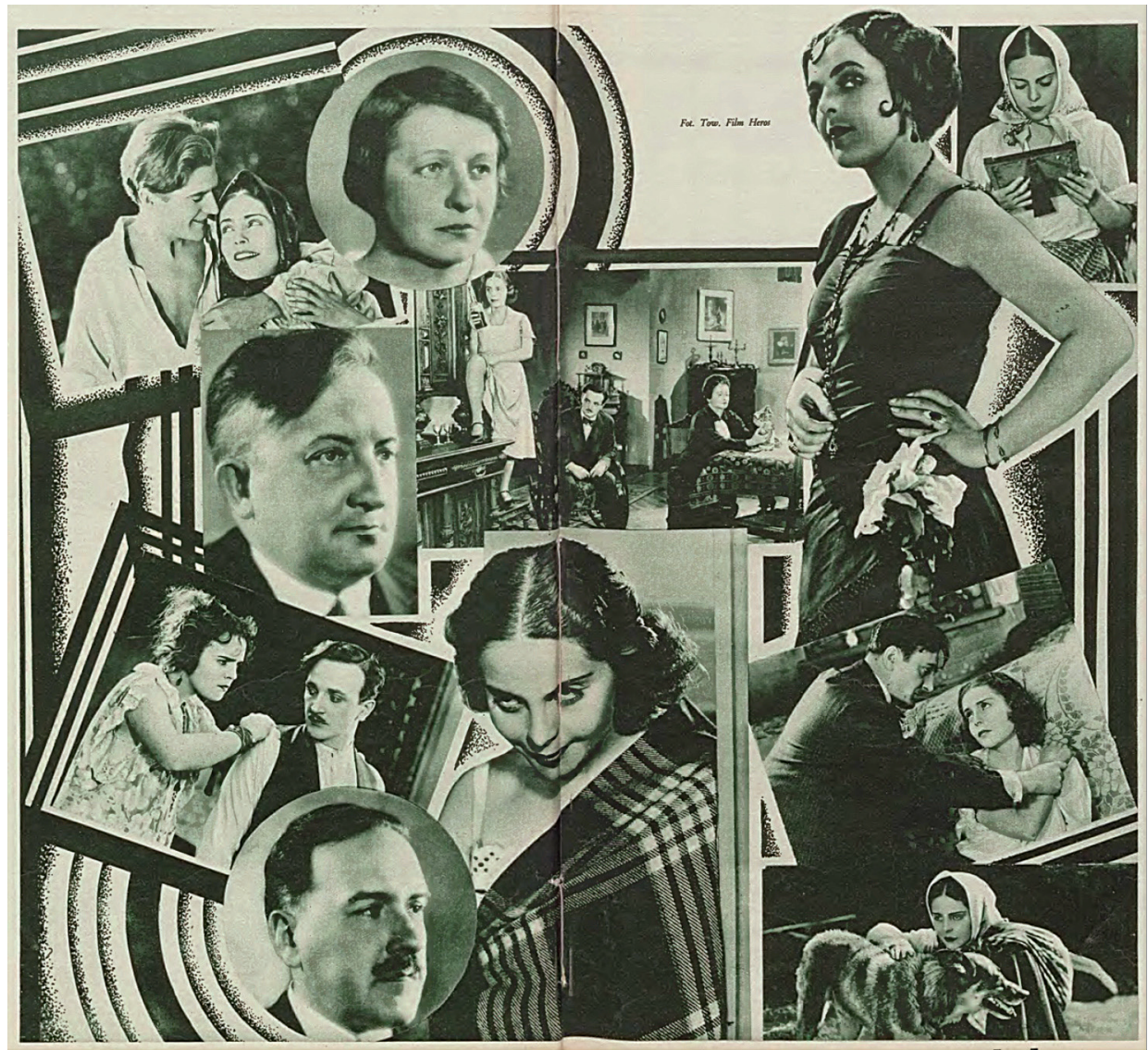

Il. I. Fotosy z filmu Moralność pani Dulskiej w: Kino I (1930) nr 4, s. 8-9, widoczni m.in. Ludomir Różycki (z lewej pośrodku) i (w medalionie) Bronisław Szulc - dyrygent.

Wszystko szło po prostu niewiarygodnie dobrze, śpiewano, kiedy trzeba, ptaszek ćwierkał, jak trzeba i co trzeba, motywy się wiązały i przeplatały z sensem muzycznym i w zgodzie z sensem zdarzeń, tempo było przyzwoite, zdjęcia z Kercelaka doskonałe, Dymsza i Krukowski pierwszorzędni, słowem cud nad Wisłą. Gdyby druga połowa jakaż szkoda, że taka płaska i pusta - była dociągnięta do pierwszej, film byłby właściwie ciekawszy od filmu René Claira, ponieważ jego dźwiękowe założenie jest szersze, nie ogranicza się do partii granych lub śpiewanych, operuje zgrabnie bogatą gamą niemuzycznych dźwięków i obejmuje wszystkie niemal momenty akcji

Dziejąca się na oczach współczesnych rewolucja wywołała falę ożywionych dyskusji. Uwagi domagała się rola kompozytorów, możliwe funkcje muzyki w filmie, konkretne koncepcje kompozytorsko-realizacyjne, a także wszelakie kwestie tech-

7 Stefania Zahorska, „Sprawy XI muzy”, Wiadomości Literackie 7 (I930) nr 5I-52, s. 6. 
niczne związane z udźwiękowieniem obrazu filmowego. Problemy te były wyraźnie reprezentowane zarówno w czasopiśmiennictwie filmowym ${ }^{8}$, jak i w muzycznym (szczególnie w Muzyce pod redakcją Mateusza Glińskiego nie unikano materiałów poświęconych aktualnym wówczas zagadnieniom modernistycznym, w tym muzyce dla filmu czy radia9 ${ }^{9}$, a także na łamach różnorakich periodyków społeczno-kulturalnych, a nawet w prasie codziennej. Zabierali głos w ich sprawie zarówno publicyści specjalizujący się w problematyce współczesnej kultury, krytycy filmowi i muzyczni oraz muzykolodzy, jak też sami kompozytorzy. Stąd charakter i forma poszczególnych ujęć są różnorodne, rozciągają się od wywiadów i reportaży poprzez teksty krytyczne i popularnonaukowe, aż po publikacje naukowe. W tym ostatnim zakresie szczególną wagę ma wydana w 1937 r. rozprawa pt. Muzyka i film Zofii Lissy ${ }^{\mathrm{Io}}$, która stanowi najpełniejsze i najbardziej wszechstronne ujęcie problemu muzyki filmowej w polskim piśmiennictwie sprzed II wojny światowej.

Wszystkie wspomniane źródła, utrzymane w rozmaitych gatunkach, stylach i sposobach wypowiadania się, tworzą fascynujący i niespenetrowany dotąd obszar badawczy, którego rozpoznanie ma istotne znaczenie dla współczesnej wiedzy o polskim kinie. Zwłaszcza, gdy uzupełniać ją z perspektywy muzykologii jako dyscypliny, dla której muzyka filmowa stanowi coraz mniej marginalizowany punkt odniesienia, wychodząc naprzeciw postulowanej od końca XX w. idei interdyscyplinarności badań nad tym zjawiskiem oraz otwarcia na heterogeniczność i wielowektorowość takich ujęćc $c^{I I}$. Celem niniejszego artykułu jest zatem wstępna charakterystyka bogatego zbioru zaczątków rodzimej refleksji o muzyce filmowej, omówienie reprezentatywnych jego przykładów, a także wytyczenie perspektyw badawczych przez nie implikowanych.

8 W tym na przykład bardzo intensywnie w najbardziej znanym periodyku filmowym międzywojennego dwudziestolecia - tygodniku ilustrowanym Kino, który wychodził nieprzerwanie od 9 III 1930 do 3 IX 1939 roku. Przed 1939 r. ukazywało się przy tym w Polsce blisko sto czasopism poświęconych filmowi, zob.: Marek Halberda, „Polska prasa filmowa do 1939 roku”, Kwartalnik Historii Prasy Polskiej 28 (1989) nr 4, s. 23-32.

9 Więcej o profilu tego czasopisma zob.: Kornel Michałowski, „Muzyka 1924-1938 (Do historii polskich czasopism muzycznych)", Zeszyty Naukowe Uniwersytetu im. Adama Mickiewicza w Poznaniu 2 (1962) nr 38, s. 98-III. W 1933 r. redakcja zapowiadała „wydanie monografii zbiorowej, poświęconej muzyce mechanicznej (film dźwiękowy)”, lecz publikacja taka nigdy się nie ukazała, zob.: „Od redakcji”, Muzyka Io (1933) $\mathrm{nr} 4-6$, s. I72.

Io Zofia Lissa, Muzyka i film. Studium z pogranicza ontologii, estetyki i psychologii muzyki filmowej, Lwów I937.

II O „miejscu refleksji o muzyce filmowej w naukach humanistycznych” a także o „muzykologii filmowej” (film musicology) wyczerpująco pisze Anna G. Piotrowska, w: O muzyce i filmie. Wprowadzenie do muzykologii filmowej, Kraków 20II, zob. zwłaszcza s. 19-28. Jeszcze inną, postulowaną przez Williama H. Rosara, kategorię stanowią „badania filmowe o charakterze muzykologicznym” (musicological film studies), zob. tegoż, „Film studies in musicology: Disciplinarity vs. interdisciplinarity”, The Journal of Film Music 8 (2009) $\mathrm{nr} 2-4$, s. 99-I25. 
2. Nim doszło w Polsce do pierwszego pokazu filmu dźwiękowego ${ }^{\mathrm{I2}}$ i pierwszej własnej realizacji, w I928 r. dyskusję o muzyce w kinie rozpoczął w łamach rodzimego czasopiśmiennictwa Łucjan Kamieński. Czas był sprzyjający - przełom dźwiękowy w kinie nabierał rozmachu; w tym samym roku ukazał się manifest pt. Przysztość filmu dźwiękowego podpisany przez Siergieja Eisensteina, Wsiewołoda Pudowkina i Grigorija Aleksandrowa, który akceptował nową drogę sztuki filmowej, choć jego autorzy nie mieli jeszcze żadnego doświadczenia praktycznego ${ }^{\mathrm{I3}}$. Kamieński także nie miał wątpliwości, że muzyka odgrywa w filmach istotną rolę, chociaż „jest to rzecz, o której się nie mówi, której się nie słucha - a przecież ją się słyszy, odczuwa się brak, gdy jej nie ma” ${ }^{4}$. Planował walczyć z przesądem „niemówienia” o niej drogą konstruktywnej krytyki, wskazywania jej celów i zadań i czuwania nad ich spełnieniem. A współczesną kondycję filmu z muzyką porównał do baletu i opery „w wieku ich dziecięcym":

I w tych formach sprężyną pierwotną był popis wzrokowo-sceniczny, rozchodziło się o urozmaicenie antraktów w komedii przez ukazanie wystawnych obrazów ożywionych przez pantomimę i muzykę - pisał. I otóż analogia: muzykę tę zestawiano, zupełnie podobnie jak po dziś dzień w kinie, z najróżniejszych utworów znanych, madrygałów, kanzonów, willanel, stosownie do wymagań sceny ${ }^{15}$.

Tym niemniej dostrzegł w bieżącej „kinomuzyce” olbrzymi potencjał rozwojowy, swoistą „improwizacyjność” i żywy, pobudzający do rozwoju ferment pozwalający mieć nadzieję na skrystalizowanie w przyszłości takiej jej formy, która sięgnie „wyżyny artystycznej”" ${ }^{16}$. Tę wizję potraktował jako punkt wyjścia do planowanej na łamach pisma dyskusji o problemach muzyki w filmie. Nie doszło do niej jednak - ukazały się bowiem tylko dwa numery tygodnika Świat Filmowy, organu nowo powstałego w Poznaniu i mającego ambitne plany Polskiego Stowarzyszenia Filmowego, na co wpływ miał niewątpliwie kryzys gospodarczy, który dotknął wszystkie wymiary filmowej branży ${ }^{17}$. Głos Kamieńskiego nie był jedynym, który w owym czasie wyszedł z poznańskiego środowiska. O muzyce filmowej mówił i pisał także Czesław Dembiński, reżyser Uśmiechów życia - filmu zrealizowanego w 1927 r. w lokalnej wytwórni Popfilm. Jego autor z jednej strony zadeklarował się wówczas jako zwolennik muzyczno-filmowych analogii w zakresie rytmu montażowego, a z drugiej - jako propagator idei synchronicznego związku ilustracji muzycznej z akcją filmu, która

27 IX 1929 r. warszawskie kino „Splendid” wyświetliło Śpiewającego btazna Lloyda Bacona z Alem Jolsonem w roli głównej.

Zob. Siergiej Eisenstein i in., „Przyszłość filmu dźwiękowego”, przekł. Tadeusz Szczepański, w: Europejskie manifesty kina. Od Matuszewskiego do Dogmy. Antologia, wybór, wstęp i opr. Andrzej Gwóźdź, Warszawa 2002, s. 58-6I.

Łucjan Kamieński, „Muzyka filmowa. Zadania i perspektywy”, Świat Filmowy I (1928) nr I, s. 6.

Ibid., s. 7.

Ibid.

Małgorzata Hendrykowska, „X muza w Poznaniu I896-I939”, Kino 20 (1985) nr Io, s. 24. 
- jak twierdził - w idealnym kształcie osiągnięta być może jedynie dzięki połączeniu funkcji dramaturga, scenarzysty, reżysera i kompozytora w jednej osobie ${ }^{18}$.

Pod koniec lat dwudziestych istotne opinie na temat muzyki filmowej sprowokował festiwal muzyczny w Baden-Baden (Deutsche Kammermusik Baden-Baden), który z inicjatywy Paula Hindemitha stał się swego rodzaju eksperymentalnym laboratorium nowej muzyki i związanych z nią zagadnień "muzyki mechanicznej”. Edycja z lipca I929 r. zawierała rozbudowaną sekcję poświęconą „Tonfilme”, a w programie znalazły się m.in. La petite Lilie Alberta Cavalcantiego z muzyką Dariusa Milhauda, Melodie der Welt (Melodia świata) Waltera Ruttmanna z muzyką Wolfganga Zellera oraz Alles dreht sich, alles bewegt sich (Wszystko wiruje - wszystko w ruchu) Hansa Richtera z muzyką Waltera Gronostaya ${ }^{\text {I9 }}$. Po festiwalu, obok relacji Ericha Steinharda zmieszczonej w Muzyce $e^{20}$, ukazał się też na łamach Wiadomości Literackich artykuł Karola Stromengera zawierający próbę systematyzacji i oceny owych eksperymentów filmowo-dźwiękowych. Wedle autora pierwsze dźwiękowce dawały się sklasyfikować w trzech kategoriach: jako „film mówiony” (z dialogami), „film szmerowy” (z autentycznymi odgłosami, np. pędzącego pociągu) oraz „film muzyczny" utrwalający grę wybitnych artystów. Osobną jakość stanowily natomiast dzieła przeznaczone „specjalnie dla odbioru filmowo-muzycznego”, takie, w których „istota nowego związku muzyki z ekranem polega na tym, aby utwór był oryginalnie pomyślany dla filmu dźwiękowego, aby w tym nowym materiale znaleźć technikę materiałowi odpowiednią" ${ }^{21}$. Autor uznał jednak, że dotychczasowe próby są nie więcej niż tylko pierwocinami, niezbyt przekonująco odzwierciedlającymi koncepcję nowej sztuki. Zamiast niej słuchacze festiwalowi mieli do czynienia a to po prostu $\mathrm{z}$,muzyką ilustracyjną” (Ruttmann/Zeller), a to ze „stylizowanym lunaparkiem” (Richter/ Gronostay). Uznanie za „pomysłowość” wzbudziły u Stromengera jedynie koncepcje Milhauda i Hindemitha ${ }^{22}$.

Kolejnym mocnym impulsem do rozwoju dyskusji nad muzyką w kinie była premiera Moralności pani Dulskiej. W marcowym numerze Muzyki z 1930 r., a więc w czasie zbiegającym się z prezentacją pierwszego polskiego filmu dźwiękowego, Mateusz Gliński dał wnikliwy przegląd obecnej kondycji tego zjawiska, próbę jego klasyfikacji oraz możliwych dróg ewolucji. $Z$ porównania jakości pierwszych filmów dźwiękowych do poziomu reprodukcji dźwiękowej, jaki reprezentowały najnowsze gramofony, wynikła pierwsza opisana przez Glińskiego kategoria współczesnego repertuaru - filmowa

I8 Czesław Dembiński, „O istocie filmu i o muzyce filmowej” [ $\mathrm{Z}$ okazji wygłoszenia odczytu na powyższy temat w „R.P.” dnia 24 marca br. o godz. I7.20], Tydzień Radiowy 2 (I928) nr I3, s. I30-I3I.

I9 Na temat eksperymentów filmowo-dźwiękowych w Baden-Baden wyczerpująco pisze Francesco Finocchiaro, w: Musical modernism and German cinema from 1913 to 1933, przekł. Elisabetta Zoni, Alex Glyde-Bates, Basingstoke 2017, zob. zwłaszcza s. I82-I85.

20 Erich Steinhard, „Baden-Baden. Doroczny festiwal muzyczny”, Muzyka 6 (1929) nr Io, s. 449-45I.

2I Karol Stromenger, „Próby filmowo-dźwiękowe w Baden-Baden”, Wiadomości Literackie 6 (1929) nr 37, s. 4. 22 Ibid. 
rejestracja fragmentów oper i rewii. Ocenił je Gliński zdecydowanie negatywnie jako wyolbrzymiające „ujemne strony szablonu operowego” i uwydatniające „zdawkowość i bezstylowość dekoracji” czy też „fałszywy patos gestykulacji i banalność reżyserii operowej”23. Nie uszły uwadze redaktora naczelnego Muzyki wady reprodukcji słowa mówionego, które wymagały intensywnych działań udoskonalających, oraz wypełniające czas oczekiwania na ich efekty dążenie do reprodukcji w filmie realnych dźwięków i szmerów, jak „szum fal, świst wiatru, łomot i hałas pędzącego pociagu, ryk rozwścieczonego tłumu i temu podobne zjawiska akustyczne"24.

Istotę kina dźwiękowego widział Gliński w połączeniu owych dźwięków i mowy z muzyką w nową jakość. Jej aktualnie najczęściej wykorzystywany komponent muzyczny nazywał „muzyką ilustracyjną”, rozumianą jako zastąpienie żywego zespołu instrumentalnego mechaniczną reprodukcją, a jednocześnie postrzegał jako zjawisko niesamodzielne i wtórne, którego jedyną „stroną dodatnią” jest synchronizacja z filmową akcją wykluczająca element przypadku. Natomiast strona brzmieniowa takiej ilustracji cierpi na drażniące niedoskonałości wynikające a to z nadmiernego wytłumienia tembru, a to jego zbytniej hałaśliwości²5. Wybiegając w przyszłość, Gliński przewidywał powstanie nowego gatunku artystycznego opartego na organicznej syntezie dźwięku i ruchu w kinie, które przybierać może różnorodne i oryginalne formy ${ }^{26}$.

O tym, że w rodzimej refleksji o muzyce filmowej silna była świadomość faktu, że wraz z końcem epoki dobierania „kawałków” przez kinowe orkiestry nadszedł czas, by zmierzyć się z ilościowym i jakościowym charakterem wybrzmiewającej z ekranu muzyki, z problemem całościowej dźwiękowości filmu, przekonują także słowa innych publicystów. Cytowana już Stefania Zahorska pisała na przykład:

Sądzę, że nie ma najmniejszej potrzeby pchania filmu na drogę całkowitego umuzycznienia, na której więcej można zepsuć aniżeli dokonać. Dźwiękowość otwiera dla filmu możliwości znacznie szersze i swoiste, nie skazuje go bynajmniej na żerowanie na terenie innej sztuki w sobie doskonałej i nietykalnej, jakkolwiek nie wynika z tego odżegnywanie się od epizodów ściśle muzycznych, od śpiewów, od wstawek orkiestralnych itd. Ale w rdzennie filmowej koncepcji czynniki te musiałyby odgrywać rolę drugorzędną, musiałyby być traktowane czy to jako kontrast, czy jako punkty kulminacyjne, akompaniament itd. ${ }^{27}$.

Z innej strony rzecz ujął Józef Fryd, który w artykule z I93I r. już w tytule podkreślił, że, by nadać muzyce w filmie dźwiękowym odpowiednią rolę, muzyk-kompozytor powinien być „współrealizatorem filmu polskiego”.

26 Ibid

27 S. Zahorska, op. cit. 
Muzyka w filmie dźwiękowym gra rolę samoistną. Ma ona wyrażać treść specjalną, jak gdyby dodatkową i odrębną od obrazów, ale łączącą się ze scenariuszem ideowo. [...] Nie można zaś skazywać muzyki do roli akompaniatora aktorów i akcji, wlokącego się, jak ciura, za obrazem

- pisał Fryd i wyrażał nadzieję na postęp w tym zakresie dzięki osiąnnięciom „doświadczonych” już kompozytorów filmowych, jak wymienieni z nazwiska Różycki i Fitelberg, czy niewspomniany wprost, ale dający się rozpoznać jako autor muzyki do Wiatru od morza Kazimierza Czyńskiego oraz Chama Jana Nowiny-Przybylskiego Jan Maklakiewicz, a także Henryk Wars (Na Sybir, Bezimienni bohaterowie), Szymon Kataszek (Serce na ulicy), Władysław Dan (Dziesięciu z Pawiaka) czy Feliks Rybicki (Rok I9I4). Nadzieją dla polskiego kina byli też, zdaniem Fryda, kompozytorzy „nowi”, jak na przykład Roman Palester pracujący wówczas nad ilustracją do Dzikich pól Józefa Lejtesa i Piotr Perkowski - autor, wraz z Marianem Neuteichem, ilustracji do filmu Wielkomiejski mrok (Rycerze mroku) ${ }^{28}$.

Inny publicysta Kina, Jerzy Braun, wyraził z kolei przeświadczenie, że jeśli wynalazek kina dźwiękowego ma stanowić adekwatnie wielki do jego rangi krok naprzód w historii X Muzy, to konieczne jest uporządkowanie i powiązanie ze sobą wszystkich, nie tylko dźwiękowych elementów konstytuujących dzieło filmowe, które dziś jawią się jako zestawienia przypadkowe:

Przyszłość dopiero będzie mogła wprowadzić ład w ten chaos mgławicowy, wytępić nieuctwo i usunąć błądzenie po omacku, tzn. czerpanie z tej nieprzebranej kopalni elementów estetycznych na oślep i bez planu. Wówczas nastąpi może epoka twórczości skrystalizowanej, epoka świadomego zestroju i kompozycji tych czynników, w których różnorodności i mnogości gubi się dziś zarówno reżyser filmowy, jak dramaturg, ilustrator muzyczny i operatorzy ${ }^{29}$.

W odniesieniu do szczegółów takiej uporządkowanej wizji ponownie zabrał głos Mateusz Gliński w odczycie radiowym z listopada I93i roku. Tekst został reprodukowany na łamach Muzyki, a „lżejszą” jego wersję opublikowało mające większe grono czytelników Kino pod znamiennym tytułem Czy film dźwiękowy już się narodzit?. Zasadniczą tezą rozważań Glińskiego było wcześniej już sygnalizowane przekonanie, że film dźwiękowy sensu stricto powinien być zupełnie nową formą sztuki:

W nowej formie syntetycznej filmu, w filmie dźwiękowym we właściwym znaczeniu tego określenia dźwięk będzie takim samym równorzędnym składnikiem całości, jak linia, jak światło, jak ruch. Składniki te stanowić będą całość organiczną, nierozerwalną. Z ruchu powstawać będzie muzyka, z muzyki - ruch. Scenariusz tworzony będzie równorzędnie we wszystkich płaszczyznach formotwórczych ${ }^{30}$.

28 J. Fryd, „Muzycy współrealizatorzy polskich filmów przed nowym zadaniem”, Kino 2 (I93I) nr 46, s. 3.

29 Jerzy Braun, „Film - to jeszcze chaos”, Kino 2 (I93I) nr 5I, s. 6.

30 Mateusz Gliński, „O filmie dźwiękowym i dźwięku filmowym” [z odczytu, wygłoszonego w radiu warszawskim, w dn. 22 XI I93I], Muzyka 8 (I93I) nr II-I2, s. 485. 
Rolę dźwięku (muzyki) widział Gliński zatem przede wszystkim w splocie z ruchem i wypełnianiu zadania współtworzenia, czy też wspierania bądź „psychologicznego" tłumaczenia akcji. Przebłyski czy też zaczyny owego stylu przyszłości dostrzegał natomiast w filmach rysunkowych oraz w dziełach René Claire’a i konkretyzował swe intuicje tymi słowy:

To co widzimy na filmach rysunkowych w formie rozhukanej, dowcipnej groteski, zobaczymy kiedyś w płaszczyźnie najrozmaitszych gatunków sztuki, w najróżnorodniejszych odmianach technicznych. W kilku fragmentach obrazów René Claire’a Pod dachami Paryża, szczególnie zaś w Milionie mamy już dziś wzory śmiałego wykorzystywania arcybogatych właściwości dźwięku filmowego. Idzie on równorzędnie z akcją, wspiera ją, tłumaczy, nadaje jej soczystości i nieznanego przedtem czaru poetyckiego. To są pierwsze zapowiedzi nowej autentycznej formy filmu dźwiękowego ${ }^{31}$.

W I93I r. Muzyka zamieściła też ważny tekst Karola Rathausa, zamieszkałego wówczas w Berlinie pioniera europejskiej muzyki filmowej. Głos kompozytora wyrósł z jego własnych doświadczeń i traktować go można jako zapowiedź szeregu późniejszych, nigdy nieopublikowanych drukiem tekstów powstałych w latach trzydziestych i przechowywanych do dziś w Bibliotece Queens College w Nowym Jorku, o których zresztą pisał wyczerpująco na tych łamach Michał Bristiger ${ }^{32}$. W artykule zatytułowanym „Problemy muzyczne w filmie dźwiękowym” ${ }^{33}$ znajdujemy taką oto autorską definicję filmu dźwiękowego:

Jest to syntetyczna forma sztuki, której elementy stanowią: obraz, szmer i głos (jako części integralne obrazu) oraz muzyka. Zasadniczym składnikiem pozostanie tu zawsze operowanie wrażeniami optycznymi. Do tych to wrażeń optycznych przyłącza się słowo mówione i śpiewane jako nowy środek ekspresji artystycznej w filmie ${ }^{34}$.

Dążenie do uzyskania organicznego zespolenia obrazu i muzyki, optyczno-akustycznej jedności Rathaus przybliżył na przykładzie swego filmu Morderca Dymitr Karamazow (Der Mörder Dimitri Karamasoff) w reżyserii Fiodora Ocepa, w którym w scenie z „trojką” „muzyka nie była [...] czymś wtórnym i podporządkowanym, lecz stanowiła koncepcję zupełnie samodzielną"35. Chodziło bowiem o fakt napisania do tej sceny utworu na orkiestrę perkusyjną, zbudowanego ze ściśle uporządkowa-

Ibid. Odwołania do filmów Claire’a jako przykładów „prawdziwych filmów dźwiękowych”, nowej formy syntetycznej sztuki znajdziemy też w pochodzącym z tego samego, I93I r., tekście Jerzego Toeplitza (zob. tegoż, „Fałsz filmu dźwiękowego. Legenda "stuprocentowca»”, Kino 2 (I93I) nr 28, s. 3.

Michał Bristiger, „Rękopisy Karola Rathausa z teorii i praktyki muzyki filmowej”, Muzyka 44 (1999) nr 4, s. 95-IIO. Bristiger zwraca uwagę, że gdyby najobszerniejszy z nich, pochodzący z I933 r., został upubliczniony, byłaby to pierwsza monografia muzyki w filmie dźwiękowym w historii, wyprzedzająca prace Leonida Sabaniejewa (Music for the films: A handbook for composers and conductors, London 1935) i Kurta Londona (Film music: A summary of the characteristic features of its history, aesthetics, technique; and possible developments, przekt. Eric S. Bensinger, London 1936), zob. ibid., s. 95 .

33 Karol Rathaus, „Problemy muzyczne w filmie dźwiękowym”, Muzyka 8 (I93I) nr Io, s. 408-4IO.

34 Ibid., s. 409.

35 Ibid. 
nych elementów formalnych i barwowych. W swym krótkim tekście kompozytor wskazał też szereg nowych środków artystycznych filmu dźwiękowego. Po pierwsze to tzw. nakładanie dźwięków, które miał umożliwić rosyjski „system Tagerowski” służący „mechaniczno-akustycznemu nakładaniu muzyki” ${ }^{36}$, po drugie - montażowe zestawienia różnych rodzajów i typów muzyki. Uwagę Rathausa zajęły ponadto kwestie orkiestracyjne, które podporządkowywał charakterowi muzycznemu filmu oraz jasności i konsekwencji, zwartości całości muzycznej. Przeczuwając, że znaczenie muzyki w filmie dźwiękowym będzie wzrastać, zwrócił także uwagę na problem współpracy kompozytora z reżyserem i puentował:

Przede wszystkim jednak poważną pracę kompozytora musi poprzedzić nie mniej poważny wysiłek nad stałym ulepszaniem artystycznotechnicznych podstaw filmu dźwiękowego. Dopiero gdy to zostanie osiągnięte, można będzie przystąpić do właściwego zadania, do stworzenia filmu dźwiękowego $-\mathrm{z}$ ducha muzyki ${ }^{3}$.

Wyrażenie zawarte na końcu artykułu wiedzie wprost ku terminologii używanej w późniejszych pismach Rathausa, w których rozróżnienie między „filmem z muzyką” (Film mit Musik) a „muzycznym filmem dźwiękowym” (Musik-Tonfilm) stanęło u podstaw idei „filmu z ducha muzyki”, pozostającego jednak w dużej mierze tylko ideałem ${ }^{38}$.

Kwestie związane z koncepcją filmu dźwiękowego jako nowej formy syntetycznej sztuki były w latach trzydziestych wielokrotnie jeszcze przywoływane przez polskich publicystów i intelektualistów. W popularnej formie ujął je ponownie Mateusz Gliński, pisząc swój esej dla Wiadomości Filmowych w 1935 roku. Ze specyfiki środków filmowych, najznamienitszych przykładów „zalążków czystego stylu filmowego” (zwłaszcza u Claire'a i w filmach rysunkowych) oraz z przekonania, że polska muzyka filmowa jest w przededniu rozkwitu, wywiódł tezę, że muzyka będzie odgrywała w tym „czystym stylu” szczególną rolę jako „zespolona organicznie z ideową osnową treści, oplatająca szczegóły, dająca tło i nastrój całej kompozycji filmowej”. Pod warunkiem wszakże, że będzie napisana przez kompozytora zorientowanego doskonale w specyfice kina ${ }^{39}$.

$\mathrm{O}$ ile postulatywna diagnoza Glińskiego miała związany z dotychczasowymi próbami rodzimych kompozytorów wydźwięk optymistyczny, o tyle w dokonanym w tym samym roku przez Antoniego Bohdziewicza „bilansie kina dźwiękowego” w ogóle nie było miejsca dla filmu polskiego, który nie dawał powodów do satysfakcji. Znalazły się w nim za to ciekawe spostrzeżenia na temat „cudownej harmonii obrazu i dźwięku” w europejskich „filmach zwykłych”, dla których niedościgłym wzorem pozostawał film rysunkowy. Autor przywołał bowiem szereg przykładów związków formalnych i emocjonalnych pomiędzy muzyką a obrazem i dookreślił wa-

36 Chodzi tu o jeden z dwóch optycznych systemów dźwiękowych wynalezionych w ZSRR, system Pawła Tagera (tagefon), który został opatentowany w 1928 roku.

37 K. Rathaus, op. cit., s. 4IO.

38 Zob. M. Bristiger, op. cit., s. 99.

39 Mateusz Gliński, „Muzyka w filmie polskim”, Wiadomości Filmowe 3 (1935) nr 4, s. 2. 
runki zaistnienia idealnego ich przymierza ${ }^{40}$. W materiale egzemplifikacyjnym znalazły się m.in. sceny taneczne z amerykańskiego filmu rewiowego, horroru Vampyr Carla Theodora Dreyera (1932), do którego muzykę napisał Wolfgang Zeller, i Niemandsland Victora Trivasa (193I) z muzyką Hansa Eislera, w którym „oprócz ludzi uległy rytmowi tańca nawet przedmioty: tańczyły talerze, potrawy i meble” ${ }^{4}$. Wśród trafnych ilustracji filmowych utworów muzycznych czy piosenek przywołał m.in. krótkometrażowe La chanson des peupliers (Topole) Jeana Epsteina, ,gdzie drzewa płyną i drżą pod wpływem wiatru w zupełnej harmonii z melodią śpiewanej pieśni”42, docenił także pierwsze filmy Claire’a oraz Operę za trzy grosze Georga Wilhelma Pabsta z muzyką Kurta Weila. Twierdzit, że

[ś]wietna muzyka Weila lepiej czuje się w filmie Pabsta niż w inscenizacjach Brechta czy Schillera. Dlaczego? Bo film łatwiej wywołuje nastrój, o jaki prosi piosenka, łatwiej go wycieniuje, podkreśli, wystylizuje... Film rozporządza w tym celu większą ilością środków. Już sam kwadrat ekranu odpowiada piosence lepiej niż nieruchome rampy teatralne. Kadr filmowy jest bardzo zmienny, samo „zbliżenie”, którego scena nie zna, ileż ułatwia! A przypomnijmy sobie ,jazdę” aparatu kinowego w clairowskim Pod dachami Paryża! To nie była tylko sztuczka techniczna, to piosence pomogło!33

Ponadto sporo miejsca poświęcił Bohdziewicz pozostałym dźwiękowym elementom filmu, a zatem mowie i „dźwiękowym autentykom”, odwołując się do wzorcowych przykładów ich zastosowania wedle zasady, „że dźwięk i obraz nie powinny "śpiewać unisono", tylko muszą szukać efektów samopas, każdy na swoim terenie"44. Jej przywołanie stanowi jawne nawiązanie do idei filmowego „kontrapunktu”, a refleksje reżysera jako całość tworzą nie tylko fachową próbę oceny dotychczasowych osiągnięć kina dźwiękowego, lecz także systematyzacji „sfery słuchowej” filmu (muzyka, mowa, dźwięki naturalne).

Fascynacja ogromnymi możliwościami prawdziwego filmu dźwiękowego i nadzieja na wysnucie z nich artystycznych konsekwencji miała jednak w polskim piśmiennictwie przeciwwagę nasyconą sporą dawką sceptycyzmu. W 1934 r. Karol Stromenger, kontynuując swe rozważania sprzed pięciu lat, przekonywał, że „absolutny” film dźwiękowy przeszedł w czas zastoju, w którym wyłomy czynią jedynie pojawiające się od czasu do czasu „dowcipne pomysły”, jak np. „efekty z opéra comique” przywołane w Milionie Claire’a. Z perspektywy Stromengera wyobrażenia „o wspólnocie wszystkich sztuk” i duecie „absolutu dźwiękowego z absolutem ruchowo-wzrokowym" były na tyle dalekie współczesnej praktyce filmowej, by nie wątpić, że pozostają przede wszystkim marzeniem ${ }^{45}$.

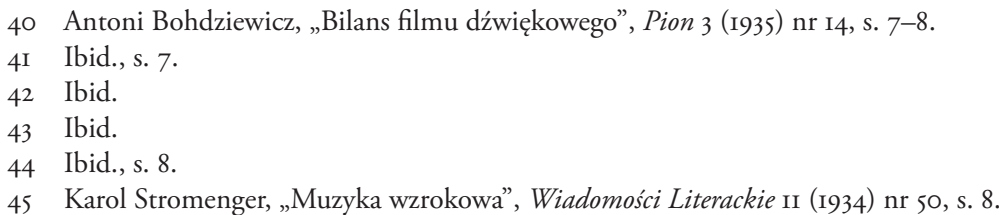


W połowie lat trzydziestych w polskiej refleksji nad muzyką w filmie pojawiały się też wątki psychologiczne. Problemem „możliwości artystycznych dźwiękowców” zajął się na przykład na łamach Czasu Adrian Czermiński. W punkcie wyjścia refleksji tego literata i dziennikarza stanęła teza o zasadniczej zmianie zadań pełnionych przez muzykę w filmie, która zaszła po dźwiękowej rewolucji. Jak twierdził, o ile wcześniej „muzyczna strona obrazu miała [...] niejako przygotowywać publiczność do optycznego przeżywania pewnych momentów, podtrzymać nastrój wywołany toczącą się akcją i wypełniać miejsca przyciszone i puste, zawarte między poszczególnymi epizodami”, o tyle muzyka w filmie dźwiękowym ma zadanie przeciwne - podkreślanie tych miejsc, „które wymagają największego skupienia i napięcia uwagi” ${ }^{46}$. Istotą wywodu Czermińskiego były wszakże spostrzeżenia na temat oddziaływania muzyki filmowej i przeżycia dzieła filmowego oparte na porównaniu strony muzycznej filmu do uzupełnienia czy też „przeciwważnika” obrazu oraz „fermaty zamykającej poszczególne obrazy”, która koordynuje „wrażenia i uczucia” 4 .

Kwestii przeżycia dzieła filmowego za sprawą muzyki poświęcony został także obszerny tekst dr. Stanisława Furmanika, historyka i teoretyka literatury, zaangażowanego zresztą w zbliżonym czasie w rodzimą dyskusję na temat muzyczności dzieła literackiego ${ }^{48}$, który pojawił się w 1936 r. na łamach Muzyki Polskiej49. Była to próba uzasadnienia naczelnej - i jak się okazało dość ryzykownej - tezy, iż „chociaż muzyka nie należy do czynników konstytutywnych filmu, jednak jej rozbrzmiewanie stanowi niezbędny warunek doznawania utworu filmowego"so. Do jej weryfikacji wiodła dość skomplikowana droga naznaczona poszukiwaniem pokrewieństwa między muzyką a filmem, którego nie sposób odnaleźć na poziomie akustycznym (jak w przypadku brzmienia słów i brzmienia tonów muzycznych), lecz daje się wychwycić po przeanalizowaniu specyficznych własności sztuki filmowej. Za platformę porozumienia Furmanik uznał „postawę imaginatywnego spostrzegania”, w który to stan - zdaniem autora - widz wprowadzany jest za pośrednictwem zapadającej na sali kinowej ciemności. Postrzega wówczas uczucia jakich doznają bohaterowie, lecz sam ich nie doznaje i nie musi doznawać. Do wzbudzenia w nim samym uczuć przyczynia się dopiero muzyka:

Gdy więc widz filmowy ma przedstawienia „konkretnych”, oznaczonych uczuć, a równocześnie sam pod wpływem muzyki zaczyna „wibrować” uczuciowo, te dwie linie przeżyć zlewają się ze sobą z łatwością i powstaje psychologiczny konglomerat, jak gdyby widz osobiście przeżywał to, co i bohaterowie. Jednym słowem muzyka umożliwia estetyczne wczuwanie się, wspótżycie w zdarzeniach imaginatywnego filmu ${ }^{\text {II }}$.

46 Adrian Czermiński, „Muzyka w dźwiękowcu”, Czas 88 (I935) nr 45 z I5 II, s. 3.

47 Ibid.

48 Zob. Stanisław Furmanik, „Dzieło literackie a muzyka”, Pion 3 (1935) nr 37, s. 5-6.

49 Stanisław Furmanik, „Muzyka w filmie”, Muzyka Polska 3 (1936) nr 5, s. 328-336.

50 Ibid., s. 334 .

5 I Ibid., s. 333 . 
Istotnym spostrzeżeniem Furmanika było przy tym wskazanie filmu abstrakcyjnego jako zjawiska, w którego zakresie muzyka najpełniej stać się może czynnikiem współtworzącym film w sposób równorzędny do materiału wizualnego. Autor docenił zwłaszcza film Themersonów Zwarcie, z muzyką młodego Witolda Lutosławskiego, bowiem pierwotny cel dydaktyczny tej produkcji zbladł wobec wyrafinowania środków wizualnych i w efekcie „, $[\mathrm{w}]$ połączeniu ze specjalnie napisaną muzyką, której płynna struktura synchronizuje ze strukturą obrazu, całość w wielu swych momentach czarowała swą niematerialną wizyjnością"s2.

Tezy Furmanika spotkały się jednak z ostrą ripostą w Muzyce, napisaną przez samego redaktora naczelnego ${ }^{53}$. Gliński zarzucał temu autorowi niewiedzę i nieznajomość różnorodności form współczesnego filmu, w których muzyka występuje w najrozmaitszych funkcjach (od filmów operowych czy tanecznych przez filmy całkiem bez muzyki i eksperymenty synchronizacyjne w filmach rysunkowych), a w konkluzji przestrzegał czytelników przed destrukcyjnym działaniem ocenianego artykułu na tych, „którzy nie będą w stanie przeciwstawić dowolnym i dość krótkowzrocznym twierdzeniom autora własnych doświadczeń i refleksji” ${ }^{4}$. Sprzeciw Glińskiego budziło przede wszystkim archaiczne przekonanie o tym, że muzyka jest warunkiem koniecznym pełnego doznania filmu, elementem podsycającym „wczuwanie się". Przeciwstawiał temu poglądowi tezę tłumaczącą zasadność występowania muzyki wyłącznie elementami treściowymi filmu. Za prawdziwą część wywodu Furmanika uznany został jedynie ustęp traktujący o filmie artystycznym, ponieważ właśnie w tym zakresie dokonywano w Polsce najdalej idących eksperymentów synchronizacyjnych 55 .

Przekonująco o roli muzyki w filmie pisał ponadto w I937 r. na łamach Kina Marian Maj. Dowodzit, że teza o pobocznej roli elementu muzycznego, którego zadaniem jest jedynie podkreślanie emocjonalnej treści obrazu czy też dawanie impulsu pobudzającego wrażliwość uczuciową widza i pozwalającego mu na „doznawanie filmu”, jest błędna. Taka koncepcja nie uwzględnia bowiem specyficznych cech sztuki filmowej, w której muzyka w pierwszym rzędzie służy „, uruchomieniu akcji” na ekranie, wywołanie złudzenia, że "widma ekranu nie znajdują się w stanie nieruchomym"s6. Maj argumentował, że muzyka akcentująca moment dramatyczny, „ruchowy” filmu, niweluje statyczność obrazu filmowego, nadaje akcji filmowej „cechy realnego życia i ruchu” i jest organicznym elementem sztuki filmowej. Przywoływał też tytuły takich współczesnych filmów (Un grand amour de Beethoven Abla Gance'a, Moonlight Sonata Lothara Mendesa), w których muzyka jest

52 Ibid., s. 336.

53 [Mateusz Gliński], „Przegląd prasy [Kilka sprostowań na temat muzyki w filmie]”, Muzyka I3 (I936) nr 7-I2, s. II3-II4.

54 Ibid., s. II4.

55 Ibid.

56 Marian Maj, „Rola muzyki w filmie”, Kino 8 (I937) nr 32, s. 3. 
„główną gwiazdą” filmowej akcji. Ten gatunek filmowy uważał zresztą za specyficzny, pełniący cenną rolę „klucza”, który umożliwia „szerokim rzeszom publiczności zrozumienie i przyswojenie sobie sensu i głębi wybitnych dzieł muzycznych"s7.

Nie ulega jednak wątpliwości, że najszersze i najbardziej wnikliwe ujęcia problematyki muzycznej w filmie były w okresie międzywojennym dziełem Mariana Neuteicha i Zofii Lissy. Dokonania Neuteicha, zamordowanego w obozie w Trawnikach kompozytora, wiolonczelisty i dyrygenta, mierzyć trzeba nie tylko wyjątkowością jego wiedzy technicznorealizacyjnej, lecz także liczbą i jakością tytułów filmów, które firmował swym nazwiskiem zazwyczaj w tandemach z innymi twórcami. Gdy chodzi o pierwszy z wymienionych zakresów, wspomnieć warto jego artykuł z I935 r., w którym Neuteich dokonał przeglądu zjawiska nazywanego „muzyką mechaniczną" ${ }^{8}$. Jej odróżnienie od „muzyki żywej” sprowadził do faktu, że znacznie rozszerza ona i zwiększa zakres procesu mechanicznego w tej pierwszej i krytycznie ocenił powszechne odnoszenie pojęcia „muzyki mechanicznej” do radia, gramofonu czy filmu dźwiękowego. W artykule Neuteicha znajdziemy precyzyjny opis zasady utrwalania dźwięku na taśmie filmowej, która wówczas całkowicie już wyparła wcześniejsze próby zapisu dźwięku w filmie. Przetworzenie zjawiska elektrycznego w optyczne kompozytor wyjaśniał m.in. poprzez działanie oscylografu przejmującego prądy elektromagnetyczne uzyskane w mikrofonie i skierowującego promień światła na światłoczułą taśmę. Taśma ta po wkopiowaniu w brzeg taśmy filmowej służy z kolei reprodukcji fal dźwiękowych za pośrednictwem fotokomórki i sprawia, że w głośnikach rozbrzmiewa ich akustyczny pierwowzór. Neuteich pisał także o innych, czysto muzycznych zastosowaniach taśmy dźwiękowej, w tym o próbach rysowania na niej dźwięku:

Już dzisiaj można narysować wprost na taśmie wzór, który podczas dźwiękowej reprodukcji wywoła efekt tonu o określonej barwie i wysokości, mimo że wykres dźwięku jest mikroskopijnie zawikłany i niesłychanie trudny do ręcznego odtworzenia. Jesteśmy dzisiaj świadkami realizacji najbardziej fantastycznych marzeń ludzkości, czy nie wolno nam wierzyć, że daleka, kilkowiekowa może przyszłość pozwoli ówczesnym kompozytorom na „rysowanie” na taśmie swoich kompozycji i wykonywanie ich wprost na aparacie, z pominięciem nut, instrumentów dzisiejszego typu i żywych wykonawców?59

Odwoływał się tym samym do przykładów metody optycznego wytwarzania dźwięku, której pionierami byli w sowieckiej Rosji Arsenij Awraamow (w Moskwie) oraz Jewgienij Szołpo (w Leningradzie). Technika ta polegała na rysowaniu figur geometrycznych (np. przedstawień równań algebraicznych, orbit molekularnych pierwiastków chemicznych) na papierze oraz przefotografowywaniu ich na ścieżkę

57 Ibid.

58 Marian Neuteich, „O muzyce mechanicznej”, Muzyka Polska 2 (I935) nr 5, s. 33-42.

59 Ibid., s. 42. 
dźwiękową taśmy filmowej, co dawało brzmienia niemożliwe do powiązania z barwą jakichkolwiek instrumentów muzycznych ${ }^{60}$. Podobne eksperymenty przeprowadzał w Niemczech Oskar Fischinger ${ }^{61}$.

Największą wagę ma jednak obszerny artykuł Neuteicha o muzyce w filmie opublikowany w 1937 roku na łamach Filmu Artystycznego, organu Spółdzielni Autorów Filmowych (SAF). Do tego stowarzyszenia należał jako współpracownik Stefana i Franciszki Themersonów, Witold Lutosławski, lecz nie on został autorem jedynego zamieszczonego w tym czasopiśmie tekstu o muzyce. Fakt ten tłumaczy nie tylko udział Neuteicha przy licznych międzywojennych polskich produkcjach filmowych jako osoby „pomagającej” kompozytorom ${ }^{62}$, ale też pozwala wnioskować, że twórca ten cieszył się sporą estymą w rodzimym środowisku filmowym.

Dla Neuteicha równouprawnienie i ścisłe zespolenie czynników wizualnych i akustycznych w filmie było faktem niekwestionowanym. Uważał, że muzyka jest w tej syntezie czynnikiem, który z jednej strony „podchwytuje” tematykę i nastrój filmowego obrazu, a z drugiej - tworzy własną, opartą na samodzielnym planie konstrukcję dźwiękową. Osiągnięcie właściwego efektu artystycznego staje się możliwe dopiero wówczas, gdy kompozytor współpracuje z reżyserem na wszystkich etapach pracy nad filmem: nie tylko przy montażu, ale też przy nakręcaniu, a nawet opracowywaniu scenariusza ${ }^{63}$.

Za podstawową możliwość wykorzystania muzyki w filmie uważał Neuteich zapewne za teoretykami sowieckimi - stosowanie jej jako „kontrapunktu” obrazu ${ }^{64}$. Kontrapunkt ten rozumiał jednak jako swoistą „równoległość” akcji dźwiękowej i wizualnej. Pośród przykładów przedstawił bowiem nie tylko montażowe przeciwstawienia, jak na przykład wykorzystanie muzyki o ponurym czy tragicznym charakterze na tle wesołej sceny masowej, które „daje widzowi reminiscencje innego planu akcji, niepokazanego w danym momencie przez reżysera"6s, lecz także opisał przypadki „kontrapunktu” polegającego na zgodności nastroju obrazu i muzyki przy jednoczesnym konstruowaniu samoistnej muzycznej formy, np. kilkugłosowej

60 Zob.: Andriej Smirnow, Sound in Z. Experiments in sound an electronic music in early 2oth-century Russia, London 20I3, s. 178.

6I Oskar Fischinger, „Klingende Ornamente”, Deutsche Allgemeine Zeitung 7I (I932) nr 30 z 28 VII.

62 Trzeba jednak pamiętać, że Neuteich był też samodzielnym twórcą ścieżek muzycznych do filmów, jak np. do Granicy Józefa Lejtesa.

63 Marian Neuteich, „Muzyka w filmie dźwiękowym”, Film Artystyczny I (1937) nr 2, s. 65. Zauważyć w tym miejscu trzeba, że w polskiej refleksji o kinie dźwiękowym lat trzydziestych problem nienależytego zespolenia warstwy akustycznej i wizualnej był często powracającym wątkiem, zob. np.: Karol Ford, „I927-I937. Io lat filmu dźwiękowego”, Świat Filmu I (I937) nr 9, s. 3 i tegoż „Przyszłość kinematografii”, Tydzień Aktualności: fllm i teatr I (1937) nr IO, s. 3.

64 Przypomnimy, że w manifeście Eisensteina, Pudowkina i Aleksandrowa chodziło o desynchronizację dźwięku w stosunku do obrazu, o umieszczenie go niejako w kontrze. Idea ta znalazła żyzny grunt zarówno w praktyce, jak i w teorii filmu, i była rozwijana. Zob. np.: Raymond Spottiswoode, The grammar of film: An analysis of film technique, Berkeley 1950 (wyd. I.: London I935).

65 M. Neuteich, „Muzyka w kinie dźwiękowym”, op. cit., s. 66. 
fugi, która - podobnie jak ilustrowana scena - posiadać będzie wzrastającą dynamikę i ekspresję. Ostrzegał jednocześnie przed niebezpieczeństwem zbyt samoistnego traktowania struktury muzycznej, która sprawić może, że właściwy kontakt między muzyką a obrazem zostanie zerwany ${ }^{66}$. Ścisłe związanie muzyki z akcją filmu mające za zadanie pogłębienie emocjonalnego wrażenia nazwał „budowaniem muzyki w głąb obrazu”, podczas gdy „kontrapunktowanie” - „działaniem wszerz” ${ }^{67}$.

W „granicach zakreślonych strukturą i tematyką obrazu” oraz chronometrażem ${ }^{68}$ widział Neuteich wielkie możliwości charakteryzowania poprzez muzykę postaci czy zdarzeń (w połączeniu z innymi zjawiskami akustycznymi), które pozostają w związku z historyczną tradycją muzyki programowej, z zastrzeżeniem, że owa plastyczna „charakterystyka muzyczna" nie powinna być nadużywana ${ }^{69}$. Odrzucił też koncepcję całkowitego „wzorowania się na tradycjach muzyki operowej i programowej”, z której zaczerpnięta została szeroko spopularyzowana technika leitmotywów w filmie. Uważał, że

ciążące nieznośnie na muzyce filmowej, naśladownictwo Wagnera, Pucciniego, Czajkowskiego, Straussa itd. święci opłakane tryumfy. [...] Tylko świadome zrzucenie balastu tradycji i doświadczeń muzyki operowej i programowej i uparte poszukiwanie odrębnych praw rządzących muzyką filmu dźwiękowego może dopomóc do stworzenia muzyki filmowej o pełnej, samodzielnej wartości, zgodnej jednocześnie z kinetyką filmuº ${ }^{70}$.

W wywodzie Neuteicha znalazło się miejsce na problem wykorzystania w filmie odgłosów realistycznych. Szczególnie interesujące wydały mu się przypadki zacierania się "granicy między dźwiękiem realistycznym a tonem muzycznym” sprawiające, że „słuchacz zatraca "zmysł akustyczny» i nie spostrzega, gdzie się kończą odgłosy a zaczyna muzyka”, jak dzieje się to na przykład w filmach rysunkowych Disneya czy Fleischera albo na konkretnym przykładzie - przy przejściu od stukotu drewnianych przedmiotów do barwy ksylofonu ${ }^{71}$. Także w połączeniach muzyki ze słowem Neuteich odnalazł wiele ciekawych aspektów, niepoddających się na razie żadnym estetycznym kanonom. Zauważał, że podstawowa różnica między łączeniem muzyki z odgłosami akustycznymi a łączeniem jej ze słowem polega na tym, że

66 Ibid.

67 Ibid.

68 Ciekawy, praktyczny opis typowego w owym czasie postępowania podczas „dopasowywania” materiału muzycznego do obrazu filmowego podał Wacław Podhorski-Okołów: „[...] długość filmu danego fragmentu odmierza się na przezroczystej taśmie, oznaczając początek i koniec sceny krzyżami. Taśmę tą wyświetla się na ekranie. Podczas wyświetlania kompozytor liczy takty, a potem poprawia utwór (skraca, dorabia), aby otrzymać odpowiednią ilość taktów. Po zinstrumentowaniu odbywają się próby zgrania się z wyświetlaną taśmą, przy czym orkiestra zaczyna grać po ukazaniu się krzyża (oznaczającego początek fragmentu) i musi zdążyć (co do jednej nuty) z sygnałem oznaczającym koniec sceny. Po kilku próbach rejestruje się dźwięki na taśmie", zob. tegoż, Kinematograf, Lwów-Warszawa 1938, s. 32-33.

69 M. Neuteich, „Muzyka w kinie dźwiękowym”, op. cit., s. 66.

70 Ibid., s. 67.

7 I Ibid. 
o ile [...] łatwe jest odbieranie równoległych wrażeń wizualnych i akustycznych, o tyle apercypowanie równoczesne wrażeń rozumowych (dialog) i czysto muzycznych jest, bez uszczerbku dla jednego z nich, prawie nieosiągalne. [...] muzyka staje się wyłącznie tłem, ułatwiając tylko widzowi poddanie się nastrojowi danej sceny ${ }^{72}$.

Za specyficzny problem uznał łączenie rozdzielonych dialogiem scen muzycznych, które wymaga ścisłej współpracy kompozytorsko-reżyserskiej, by ustrzec się z jednej strony przed zdeformowaniem konstrukcji muzycznej, a z drugiej przed „przykryciem” tekstu przez muzykę. Postulował ścisły kontakt kompozytora z techniką filmu, a zatem konieczność zdobycia wiedzy o warsztacie filmowym i tajnikach montażu, a także pewnych umiejętności praktycznych. Zapewne tymi właśnie atutami sam torował sobie drogę w rodzimym świecie filmowym. Konkludował zaś radością z faktu, iż wielu kompozytorów „o wielkich imionach” (np. Prokofiew, Honegger, Milhaud) tworzy muzykę do filmów, doceniając „kolosalne” techniczne i artystyczne możliwości muzyki filmowej ${ }^{73}$.

Co ciekawe, niemal analogiczne spostrzeżenia zawiera opublikowana w tym samym 1937 r. książka Zofii Lissy - Muzyka i film.

Fakt, że twórcy tej miary, co Schönberg, Auric, Honegger, Ibert, Milhaud, Prokofiew, Weill, Rathaus i in., z polskich kompozytorów Maklakiewicz i Palester, zaczynają interesować się muzyką filmową, pozwala mieć nadzieję, że muzyka nowoczesna zwycięsko wkroczy na teren filmu ${ }^{74}$

- pisała Lissa w jednym z rozdziałów swego wyczerpującego wykładu, w którym poświęciła uwagę muzyce nowoczesnej w filmie. Powstanie książki poprzedziły nie tylko doświadczenia autorki jako kinowego widza ${ }^{75}$, lecz także jej działalność w 1. 1933-36 w lwowskim Klubie Filmowym „Awangarda” związana także z publikacjami na łamach pisma Awangarda: Niezależny Tygodnik Ilustrowany Poświęcony Sprawom Teatru, Kina i Radia oraz klubowymi prelekcjami i pogadankami radiowymi, które prowadziła, wykorzystując swą wiedzę naukową i doświadczenie akademickie ${ }^{76}$.

Lissa uznawała film za sztukę syntetyczną odwołującą się do sfery wzroku i słuchu zsyntetyzowanych w ruchü77. W tym ujęciu warstwę słuchową (tj. ilustrację muzyczną) filmów dźwiękowych konstytuują cztery zasadnicze elementy: szmery, muzyka właściwa, mowa ludzka i - mająca znaczącą rolę ekspresyjną - cisza $^{78}$.

\footnotetext{
Ibid., s. $67-68$.

Ibid., s. 69.

Z. Lissa, Muzyka i film, op. cit., s. 132.

Zofia Lissa, Estetyka muzyki filmowej, Kraków 1964, s. II.

$76 \mathrm{Na}$ temat tego czasopisma wyczerpująco pisze Małgorzata Radkiewicz, „Publicystki lwowskiej Awangardy o «sprawach teatru, kina i radia»", Kultura Popularna I2 (2015) nr 4, s. 56-67.

77 Zauważmy, że analogiczna teza przewijała się w polskiej refleksji o kinie dźwiękowym od czasu pierwszej publikacji Mateusza Glińskiego (1930). Jej zbieżność z przywoływanymi wyżej poglądami Neuteicha sama Lissa odnotowała w przypisie, zob. tejże, Muzyka i film, op. cit., s. 8.

78 Ibid., s. 45. Wstępne tezy na ten temat Lissa przedstawiła w referacie pt. Funkcje muzyki w utworze filmowym, który wygłosiła na posiedzeniu Sekcji Estetyki III Polskiego Zjazdu Filozoficznego w Krakowie w 1936 roku. Wymieniła wówczas tylko trzy konstytuanty sfery słuchowej filmu: muzykę, szmery
} 
Zauważała, że film dźwiękowy nie tylko rozszerzył znacznie materiał sfery słuchowej filmu, lecz także - zwłaszcza w filmach artystycznych - w pewien sposób ją ujednolicił, wykorzystując jednocześnie różnorodność jej elementów do specjalnych efektów. Za najistotniejsze uznać jednak trzeba ustalenia Lissy dotyczące podziału funkcji sfery akustycznej w filmie dźwiękowym. Zostały one wszak zasadniczo utrzymane w późniejszej Estetyce muzyki filmowej79 i po dziś dzień są praktycznie wykorzystywane (z uzupełnieniami dotyczącymi nowych czy bardziej zaawansowanych funkcji współczesnej praktyki filmowej) w pracach badawczych ${ }^{80}$. Przypomnijmy zatem, że - wedle pierwotnej, opartej na kategoryzacji ontologicznej i psychologicznej, koncepcji Lissy - rolą kompleksowo pojmowanych zjawisk dźwiękowych w filmie jest:

- podkreślanie struktury ruchów zjawisk wzrokowych (analogie wzrokowo-słuchowe), co ułatwia widzowi skupianie się na tych czynnikach, które z reżyserskiego punktu widzenia są w danej chwili najważniejsze ${ }^{8 \mathrm{r}}$;

- reprezentowanie zjawisk wzrokowych nie danych na filmie naocznie (funkcja uzupełniająca), jak np. stuk miecza katowskiego dający znać o dokonaniu egzekucji ${ }^{82}$;

- stylizacja szmerów przynależnych do przedstawionych przedmiotów i uzupełnianie przedmiotów przedstawionych na ekranie ich korelatami akustycznymi w formie realistycznej ${ }^{83}$;

- użycie mowy jako reprezentacji sfery znaczeniowej, w tym „mowy zwielokrotnionej”, tj. np. okrzyków tłumu czy odgłosów dziecięcego gwaru ${ }^{84}$;

- występowanie muzyki w swej naturalnej roli (w scenach muzycznych ${ }^{85}$;

- podkreślanie reprezentowanych przez obraz stanów psychicznych bohaterów i reprezentowanie stanów psychicznych, które nie są dane wzrokowo ${ }^{86}$;

- stwarzanie podstawy do wczuwania się w nastrój obrazu dzięki temu, że muzyka działa bardziej bezpośrednio na swoich odbiorców niż inne rodzaje sztuk oraz rozszerzanie kręgu skojarzeń odbiorcy filmowego ${ }^{87}$;

i dźwięki mowy, zob.: Zofia Lissa, „Funkcje muzyki w utworze filmowym”, Przeglad Filozoficzny 39 (1936) $\mathrm{nr} 4$ Ksiegga pamiatkowa III Polskiego Zjazdu Filozoficznego w Krakowie, s. 457-458. Jednym z pierwszych świadectw teoretyzowania Lissy na temat muzyki filmowej pozostaje jej artykuł pt. „Psychologiczne podstawy muzyki filmowej”, Lwowskie Wiadomości Muzyczne i Literackie Io (1933) nr 78, s. 2.

79 Zob. przyp. 75. Książka Lissy w niemieckim tłumaczeniu Lothara Fahlbuscha i Katji Weintraub ukazała się jako Ästhetik der Filmmusik w 1965 r. w Berlinie.

80 Do klasyfikacji Lissy odwołuje się np. Philip Tagg w Music's meanings. A modern musicology for non-musos, New York-Huddersfield 2013, s. 546-550. Zob. też: Roberto Calabretto, „Listening to images: A historical overview of theoretical reflection", w: Musical listening in the age of technological reproduction, red. Gianmario Borio, London-New York 2015, s. 167-184.

8I Z. Lissa, Muzyka i film, op. cit., s. 58-62.

82 Ibid., s. 62-65.

83 Ibid., s. 65-69.

84 Ibid., s. 69-72.

85 Ibid., s. 73-75.

86 Ibid., s. 75-82.

87 Ibid., s. 82-85. 
- funkcjonowanie symboliczne - odnoszące się nie do jednego, lecz do kompleksów i wzajemnych relacji zjawisk wzrokowych ${ }^{88}$;

- formalne jednoczenie fragmentów sfery wzrokowej, które przekłada się na zasadę, że zmianie muzyki nie musi towarzyszyć zmiana obrazu, natomiast zmiana muzyki musi mieć swe konsekwencje w zmianie obrazu ${ }^{89}$.

Wśród kwestii rozważanych przez Lissę w omawianym opracowaniu znajdziemy także spostrzeżenie, że powiązanie sfery dźwiękowej ze wzrokową najsilniejsze jest $\mathrm{w}$ filmie abstrakcyjnym i rysunkowy $\mathrm{m}^{\circ 0}$, ponadto pojawią się uwagi na temat komizmu w muzyce filmowej ${ }^{91}$ i przemyślenia na temat specyfiki słuchania muzyki filmowej w odróżnieniu od słuchania „muzyki czystej”92. Interesowały ją również takie zagadnienia szczegółowe, jak relacja muzyki filmowej do operowej³ , problemy formy (technika motywów przewodnich, cytatu muzycznego, wiązania akcji przez ten sam podstawowy utwór muzyczny lub melodię-piosenkę) $)^{94}$ czy rola muzyki w filmach historycznych i egzotycznych ${ }^{95}$, a także - co już sygnalizowano - kwestia funkcjonowania muzyki nowoczesnej w filmie. Teza związana z tym ostatnim $\mathrm{z}$ wymienionych problemów warta jest przytoczenia niemal w całości:

[...] muzyka nowoczesna jest bardziej zrozumiała w swej niezwykłej dla ucha przeciętnego słuchacza formie brzmieniowej, jeśli występuje w związku z obrazem filmowym, aniżeli wtedy, gdy dochodzi do słuchacza jako muzyka sama dla siebie. Obcość brzmienia muzyki nowoczesnej, która, wprowadzając nowe kategorie stylistyczne, jest niezrozumiała nawet ludziom o wysokiej kulturze muzycznej (opartej na muzyce dawniejszej), zanika w pewnym stopniu na terenie filmu. Kompleks brzmień, posiadający swoje wzrokowo uchwytne objaśnienie w postaci obrazów filmowych, mający podobną do zjawisk wzrokowych jakość ogólną, jest bardziej zrozumiały na tym miejscu, aniżeli wtedy, kiedy słuchacz musi dopiero szukać, domyślać się tych ruchów, czy tych treści psychicznych, które leżą u podstaw danych struktur dźwiękowych. [...] Obraz dostarcza tu muzyce treści ogólnie zrozumiałych. Pomaga zatem do rzutowania w obce i niezwykłe struktury dźwiękowe treści wzrokowo uchwytnych i zrozumiałych. Zjawiska ekranu, podając naocznie treści, łączące się wewnętrznie z tego rodzaju ilustracją muzyczną, nadają samej muzyce jej sens, przekonują słuchacza (który przeważnie odnosi się negatywnie do muzyki, której nie umie uchwycić), że i ona nadaje się do wyrażenia pewnych treści ${ }^{96}$.

Ma ona wielkie znaczenie w perspektywie prowadzonych przez Lissę badań psychologicznych, które odnosiły się także do problemów percepcji muzyki nowej,

88 Ibid., s. $85-88$.

89 Ibid., s. 88-93.

90 Ibid., s. 96-IO7.

$9 \mathrm{I}$ Ibid., s. IO8-II3.

92 Ibid., s. II4-I23.

93 Ibid., s. I24-I26.

94 Ibid., s. I26-I3O.

95 Ibid., s. I32-I34.

96 Ibid., s. I3O i I32. 
a jedną z pierwszych konkretyzacji znalazły w opublikowanym w tym samym roku co rozprawa o muzyce i filmie artykule pt. O stuchaniu i rozumieniu utworów muzycznych ${ }^{97}$. Twierdziła w nim m.in., że o „niezrozumiałości” muzyki modernistycznej dla przeciętnego słuchacza decyduje mechanizm wykształcania się w pamięci pewnych formuł organizujących, do których muzyka ta nie przystaje. Trzeba jednak zauważyć, że problem użycia muzyki nowej w filmie jako sposobu na przezwyciężania trudności percepcyjnych i „oswojenia” słuchacza z nowoczesnymi brzmieniami pozostał w dużej mierze w sferze życzeniowej. Lissa bowiem sama przyznawała, że świadectw funkcjonowania modernistycznej muzyki w filmie zna niewiele, a przestrzeń ta jest zdominowana przez muzykę „łatwo wchodzącą w ucho"98. Tym niemniej problem powyższy prowadzi do ostatniej grupy źródeł, na podstawie których rekonstruować dziś można obraz rodzimej refleksji o muzyce w filmie, w pierwszej dekadzie rozwoju jego postaci dźwiękowej. Tworzą ją wypowiedzi pracujących dla kina kompozytorów, nie mające wprawdzie - jak przywoływane wyżej teksty Rathausa czy Neuteicha - rangi złożonego ujęcia, lecz będące świadectwem preferencji estetyczno-stylistycznych niektórych twórców oraz problemów wynikających z realizacji ilustracji muzycznej.

Kompozytorem, któremu na łamach czasopiśmiennictwa z okresu międzywojennego niejednokrotnie oddawano głos jako autorytetowi w dziedzinie muzyki filmowej, był Jan Adam Maklakiewicz. Już w I93I r. Kino cytowało jego wypowiedź dotyczącą dotychczasowych doświadczeń w tym zakresie.

- Jak należy według pana robić ilustrację muzyczną dźwiękowca?

- Muzyka dźwiękowa musi być dość przystępna, lecz motyw powinien być łatwy i miły. Jeśli chodzi o mnie, to oprócz głównego leitmotywu używam pobocznych motywów, ilustrujących poszczególne osoby. Ten sposób ilustrowania zapożyczony jest od Wagnera i jest o tyle dobry, o ile główny motyw przechodzi muzycznie analogiczne koleje i zmiany, jak i związany z nim bohater. Należy przy tym unikać szablonu i umiejętnie, a nieraz dowcipnie przechodzić z jednego do drugiego nastroju, z jednego do drugiego wariantu tej samej melodii. Ilustrator filmu dźwiękowego powinien być zarazem wytrwanym instrumentatorem 9 .

W 1933 r. z kolei, po premierze Sabry Aleksandra Forda, wywiadu dla czasopisma Kino dla wszystkich udzielił młody twórca muzyki do tego filmu, Szymon Laks. Pracę swą skomentował poniższymi słowy:

97 Wiedza i Życie I2 (1937) nr 6, s. 383-395. Przedruk w: Zofia Lissa, Wybór pism estetycznych, Kraków 2008, s. 173-186. Jednak teksty o podobnej tematyce Lissa publikowała już na początku lat trzydziestych, zob. tejże: „O słuchaniu «nowej» muzyki”, Lwowskie Wiadomości Muzyczne i Literackie 7 (1930) nr I2, s. 2.

98 Z. Lissa, Muzyka i flm, op. cit., s. 132.

99 Jerry [Jerzy Ryba], „Muzyka w kinie. Kompozytorzy i muzycy zabierają głos”, Kino 2 (1931) nr 26, s. I2. Z kolei cytowany przez Jerry’ego (w kolejnym odcinku serii wywiadów z muzykami) Władysław Dan w odniesieniu do pracy nad planowanymi Dziesięciu z Pawiaka deklarował: „jestem przeciwnikiem lejtmotywów dla poszczególnych osób, lejtmotywy będę odnosił nie do ról, a do scen”, zob.: Jerry, „Muzyka w kinie (dokończenie)”, Kino 2 (I93I) nr 27, s. 6. 
Sabra była dla mnie wdzięcznym polem do popisu, a to dzięki egzotyczności tła i żywotności problematów tego filmu. Melodie przewodnie nie ilustrują w tym wypadku osób głównych - jak to przeważnie bywa w filmie muzycznym - raczej odnoszą się one do elementów przyrody, pustyni, wody, roślinności albo do instynktów ludzkich - głodu, pragnienia, tęsknoty itp. Starałem się o możliwie daleko idące uprzystępnienie wyrazu muzycznego, co jest i krępujące, i fascynujące zarazem ${ }^{\text {Ioo }}$.

Przy okazji Laks zdradził nazwiska swych „przewodników artystycznych” w osobach Jacquesa Iberta, Kurta Weilla i Karola Rathausa oraz zadeklarował się jako entuzjasta postępu technicznego we współczesnym kinie ${ }^{\text {Ior }}$.

Obydwie wypowiedzi potwierdzają, że w pierwszym okresie rozwoju kina dźwiękowego w Polsce powszechnie akceptowaną techniką strukturowania filmowej partytury była odnoszona do zróżnicowanych elementów obrazu technika motywów przewodnich, ta sama, której nadmierne rozpanoszenie się w filmie krytykował kilka lat później Marian Neuteich. Wskazują też, że kompozytorzy musieli mierzyć się z koniecznością „uprzystępnienia” warstwy muzycznej filmu.

To bynajmniej nie wszystkie tropy problemowe, jakie w zakresie muzyki filmowej lat trzydziestych wytyczają wypowiedzi polskich kompozytorów. Po różnorodnych doświadczeniach związanych ze skomponowaniem ilustracji do filmów takich jak Cham, Pod Twoja obrone i Przybtęda Maklakiewicz skłonny był podzielić się z czytelnikami filmowej prasy także przemyśleniami na temat roli muzyki w filmie. Postrzegał ją jako uzależnioną od tematyki obrazu i środowiska akcji filmowej, a wśród jej funkcji wymienił: łączenie ze sobą scen, podkreślanie akcji, dopowiadanie, wspomaganie widza w odczuwaniu akcji oraz podkreślanie natężenia silnych emocji ${ }^{\text {Io2 }}$. W innej swej wypowiedzi zasygnalizował ponadto specyficzną grupę problemów kompozytorskich, które stanowiły przeszkodę na drodze ku podnoszeniu poziomu artystycznego polskiego filmu:

Zazwyczaj za granicą ilustracje muzyczne do filmów pisze kilku kompozytorów, w zależności od rodzaju muzyki: lekkiej czy poważnej. Natomiast nad instrumentacją i nagrywaniem czuwa poważny, wytrawny muzyk. U nas bywa różnie. Rozumiem doskonale, że każdy chce żyć, że każdy chce zarobić. Nie rozumiem natomiast wytwórców, że angażują do komponowania muzyki do filmów coraz częściej muzyków kawiarnianych, nieraz bardzo utalentowanych w swoim zakresie, którzy jednak muzykę do instrumentowania oddają różnym dyletantom lub uczniom, płacąc im grosze za to. W końcu wychodzi zazwyczaj „szmira”, pomagająca czynnie do upadku polskiego filmu ${ }^{\mathrm{ro3}}$.

Rok później, w odpowiedzi na ankietę Wiadomości Filmowych „w sprawie udoskonalenia filmu polskiego”, Maklakiewicz zwrócił także uwagę m.in. na nadmierne oszczędności „na muzyce”, jakie praktykują producenci, na cenzorskie skróty w filmie,

Ioo Zob.: „Strona muzyczna filmu Sabra”, Kino dla Wszystkich 8 (I933) nr 4I, s. I2.

IOI Ibid.

IO2 „Wywiad z prof. Janem Maklakiewiczem, twórcą ilustracji muzycznej do filmu Przybtęda”, Wiadomości Filmowe I (1933) nr I2, s. 4.

IO3 Jan Maklakiewicz, „O udźwiękowianiu filmów”, Kalendarz Wiadomości Filmowych 8 (I933), s. 23. 
w wyniku których wycina się z taśmy muzykę, rujnując tym samym jej ciągłość oraz sformułował postulaty, które pozostają w analogii z innymi - cytowanymi powyżej wypowiedziami dotyczącymi konieczności udziału kompozytora w pracy nad filmem już od momentu opracowywania scenariusza. „Muzyk powinien być jednym z czynników twórczych obok scenarzysty, reżysera, dekoratora i artysty” - podkreślał ${ }^{\mathrm{ro4}}$.

3. Dokonany tu przegląd najlepiej uchwytnych, najczęściej powracających i - jak się zdaje - najistotniejszych wątków wczesnej polskiej refleksji o muzyce w kinie dźwiękowym nie rości sobie prawa do kompletności. Takowy musiałby być oparty na znacznie bardziej wnikliwych niż te, które wykonano na potrzeby niniejszego artykułu, poszukiwaniach źródłowych. Tym niemniej skomentowany tu wybór może już stać się podstawą do próby wytyczenia perspektyw dalszych badań tak nad samym przedmiotem, tj. świadectwami muzyczno-filmowej refleksji w okresie międzywojennym, jak i nad muzyczno-filmową praktyką tego czasu.

W pierwszym zakresie zmieszczą się z pewnością choćby badania porównawcze, odnoszące rodzime próby teoretyzowania na temat muzyki w filmie czy modernistyczne marzenia o tworzeniu nowych, syntetycznych jakości artystycznych do siebie nawzajem oraz do współczesnych im ponadlokalnych koncepcji estetyczno-teoretycznych odpowiadających na przełom dźwiękowy w kinematografii. Drugi zakres wydaje się szczególnie pojemny. Z perspektywy muzykologicznej na plan pierwszy wysuwa się, rzecz jasna, kwestia kształtowania warstwy muzycznej w filmie pierwszych lat jego dźwiękowej postaci wymagająca bezpośrednich studiów analitycznych nad zachowanym materiałem audiowizualnym. Na uwagę zasługuje z pewnością zróżnicowanie stylistyczne i gatunkowe tej muzyki, a także poszukiwanie odpowiedzi na pytania o to, na ile wzorem były dla niej rekomendowane przez znawców zjawiska współczesne i możliwe funkcje ${ }^{\mathrm{IO} 5}$, na ile stanowiła ona nową, autonomiczną jakość, a w jakim zakresie podatna była na naciski tzw. branży. Ważki przedmiot badań stanowić może w tym kontekście piosenka, której filmowe i pozafilmowe życie śledzić można na imponującej liczbie przykładów.

I04 „Kompozycja muzyczna dla filmu polskiego. Wywiad z prof. J. Maklakiewiczem”, Wiadomości Filmowe 2 (I934) $\mathrm{nr}$ 2I, s. I. Postulat ten pozostał aktualny także przynajmniej w pierwszym powojennym dziesięcioleciu dziejów polskiego kina, z czego zdaje sprawę Iwona Sowińska, przytaczając m.in. wypowiedzi Artura Malawskiego i Kazimierza Serockiego, zob. tejże: Polska muzyka filmowa 1945-1968, Katowice 2006, s. 36-40.

Ios Trzeba zauważyć, że w książce o muzyce i filmie Zofia Lissa tylko dwukrotnie sięgnęła po przykłady z dorobku rodzimej kinematografii. Jednym była Europa Themersonów, drugim - trudny dziś do właściwego zidentyfikowania film pt. Burza nad Tatrami. Taki tytuł nie pojawia się bowiem w żadnej z dostępnych baz danych (internetowych i drukowanych) na temat filmu polskiego. „Tatrzańskie” filmy realizował wprawdzie w latach trzydziestych Adam Krzeptowski (Biaty ślad, 1932 i Zamarte echo, 1934), w fabułę drugiego z nich wpleciona jest burza i „poszukiwania zaginionych taterników”, o których pisze Lissa, lecz tytuł dokładnie odpowiadający przytoczonemu przez autorkę ma tylko zrealizowany w 1932 r. film czechosłowacki (Boure nad Tatrami), zob.: Z. Lissa, Muzyka i film, op. cit., s. 79 i 98. 
Omówiony powyżej wycinek rodzimej refleksji o muzyce w kinie dźwiękowym otwiera też niewątpliwie ciekawą perspektywę badania „filmowych biografii” polskich kompozytorów oraz badania polskiej muzyki filmowej jako „muzyki współczesnej”. W komponowanie dla filmu byli bowiem w latach trzydziestych zaangażowani zarówno przedstawiciele środowiska muzyki poważnej, jak cytowani bezpośrednio Maklakiewicz, Laks czy Neuteich (a także m.in. Roman Palester, Feliks Rybicki, Piotr Perkowski, Michał Kondracki, Witold Lutosławski, Andrzej Panufnik), jak i muzycy „rozrywkowi”, w tym renomowani band-leaderzy polskich zespołów jazzujących (np. Henryk Wars, Zygmunt Karasiński, Szymon Kataszek). Przy tym w publicystyce lat międzywojennych nietrudno znaleźć przykłady ubolewania nad stosunkowo małym zaangażowaniem twórców „poważnych” w aktywność dla rodzimego kina. Stefan Rawicz w 1938 r. szukał na przykład przyczyn braku zainteresowania filmem przez Karola Szymanowskiego i sam sobie odpowiadał: „bo nie było nikogo, kto by z Szymanowskim temat ten poważnie i wszechstronnie omówił”' ${ }^{\prime \prime 6}$. Receptą na tego rodzaju bolączki miało być głębsze porozumienie producenta z potencjalnym twórcą muzyki, które sprawi, że praca filmowa stałaby się dla niego nie tylko „nie najgorszym źródłem dochodu” ale również realnym „źródłem natchnień twórczych” ${ }^{\text {Iо7. }}$

Jeśli zatem powiedzieć można, że rodzima praktyka muzyki filmowej w pierwszej dekadzie rozwoju filmu dźwiękowego w Polsce nie nadążała za teorią, za wizją nowej formy sztuki dźwiękowej mającej samodzielną i niekwestionowaną wartość artystyczną, która w latach trzydziestych ubiegłego stulecia rozpalała wyobraźnię krytyków, intelektualistów i samych artystów tworzących dla filmu, to także stwierdzić trzeba, że w polskim piśmiennictwie do 1939 r. kwestie muzyki w filmie zajmują miejsce niemarginalne. Stanowią ważną część wczesnej rodzimej myśli filmowej ${ }^{\text {I08 }}$, a jednocześnie fragment dziedzictwa polskiej refleksji o muzyce - takiej, której wynalazek kina dźwiękowego nadał zupełnie nowe funkcje, znaczenia i powinności. Ten zakres tematyczny z pewnością mógłby stać się przedmiotem głębszego zainteresowania pośród muzykologów chcących przenieść swą wiedzę i doświadczenie na specjalizację filmową.

Io6 Wedle relacji Władysława Szlengla dotyczącej niedokończonego wywiadu telefonicznego dla czasopisma Kino, Szymanowski miał wówczas powiedzieć: „[...] sądzę, że dzisiejsza forma sztuki filmowej - ten gorączkowy, nerwowy, oparty wyłącznie na tempie i ogłuszeniu jazzem, elaborat filmowy, jaki do spożycia dostaje publiczność - daje mało możliwości dla wypowiedzenia się muzyce poważnej. Film oparty na takiej muzyce musiałby być zupełnie czymś innym, czymś nowym, zupełnie inaczej spreparowanym. Nie wyobrażam sobie w tej chwili tematyki, która by pozwoliła muzyce grać równorzędną rolę z akcją, a tylko w takim zestawieniu muzyka poważna ma rację bytu na ekranie", zob.: Władysław Szlengel, „Niedokończony wywiad z Karolem Szymanowskim”, Kino 8 (1937) nr I5, s. 3.

I07 Stefan Rawicz, „Muzycy i film”, Wiadomości Filmowe 6 (1938) nr 4, s. 2.

I08 W antologii Jadwigi Bocheńskiej (Polska myśl filmowa do roku 1939, Wrocław 1977) zawarte zostały cytowane w tym artykule teksty Stanisława Furmanika i Jerzego Toeplitza, a także fragment książki Zofii Lissy. 


\section{POLISH REFLECTIONS ON MUSIC IN SOUND FILM IN THE I93OS.}

MAJOR IDEAS AND PERSPECTIVES OF MUSICOLOGICAL RESEARCH

In Poland, the first evidence of reflections concerning music sounding directly from the screen precedes the premiere of the first Polish sound film Moralność pani Dulskiej ([The Morality of Mrs Dulska], 1930). The subject was discussed in various types of periodicals, the discussion assumed different forms, and the participants included both columnists and active members of the artistic circles associated with cinema and music.

As early as in the late I920s, researchers such as Kamieński and Dembiński noticed the vast potential of 'cinematic music' and the need to synchronize the music setting with the plot of a film. After the presentation of film music at the Music Festival in Baden-Baden (1929), an attempt was made to introduce a systematic categorization of the pioneering sound films (Stromenger).

In the I930s, Mateusz Gliński addressed the subject of sound film several times, giving an overview of its then-current condition, and envisioning possible paths for its development, leading to the emergence of a new, synthetic form of art that would combine sound and movement. The issue of the acoustic layer of a film perceived holistically was also discussed by other journalists (Zahorska, Fryd, Braun), filmmakers (Bohdziewicz) and composers (Rathaus). They usually identified an ideal model for such a synthesis in animated films and René Claire's movies. According to Rathaus, the artistic vision combining image, sound and music into a visual-acoustic whole was linked to the ideal of a 'sound film from the spirit of music'.

In addition, in the reflections on sound film in Poland psychological themes were also present (e.g. Czermiński and Furmanik), and concerned the role of music in the viewer-listener's experience of the film. The most comprehensive and insightful approaches to film music were expressed by Marian Neuteich and Zofia Lissa in 1937. Both authors regarded the sound film as a synthetic form of art appealing to the visual and aural senses, and paid special attention to the functions of music with respect to image, and its relationship to other acoustic elements in a film. Lissa proposed an exhaustive systematization of the functions of the acoustic layer of a film and discussed a number of detailed issues, including the functioning of modern music in cinema. On the other hand, composers who provided music settings to Polish films (including Maklakiewicz and Laks) usually focused on the specific demands of their task and proposed that the composer take part in the film-making process from the early stages such as writing the script, a demand also supported by journalists.

All the sources quoted above are undoubtedly valuable material for film-related musicological research, focused on such subjects as style, genre and function, 'film biographies' of Polish composers, or studies into Polish film music perceived as 'modern music'.

Translated by Pawet Gruchata

Dr hab. Iwona Lindstedt, adiunkt w Zakładzie Teorii i Estetyki Muzyki Instytutu Muzykologii Uniwersytetu Warszawskiego. Jej zainteresowania badawcze skupiają się na historii, teorii, estetyce muzyki i analizie dzieła muzycznego w odniesieniu do twórczości XX i XXI wieku. Specjalizuje się także w zakresie metodologii. Od roku 2016 pełni funkcję redaktor naczelnej Polskiego Rocznika Muzykologicznego. Autorka m.in. monografii Dodekafonia i serializm w twórczości kompozytorów polskich XX wieku (Lublin 200I), Sonorystyka w twórczości kompozytorów polskich XX wieku (Warszawa 20Io). i.lindstedt@uw.edu.pl 